\title{
ВИНДИКАЦИЯ ЖИЛОГО ПОМЕЩЕНИЯ У «ДОБРОСОВЕСТНОГО ПРИОБРЕТАТЕЛЯ» С ПОЗИЦИИ ВЕРХОВЕНСТВА ПРАВА
}

\begin{abstract}
Аннотация: Настоящая статья посвящена поиску правового решения проблемь столкновения притязаний не владеющего жильм помещением собственника с притязаниями владеющего этим жильм помещением не собственника - «добросовестного приобретателя» - в аспекте реализации принципа верховенства права. Правовое регулирование вопросов виндикации жилого помещения у «добросовестного приобретателя» оценено на соответствие трем составляющим принципа верховенства права, а именно: требованию правовой определенности, требованию правовой эффективности и требованию соблюдения баланса интересов (пропоричинальности). В результате исследования выявлено несоответствие перечисленным требованиям процесса истребования жилого помещения у «добросовестного приобретателя». В связи с чем, установлена необходимость в формулировании критериев оценки выбытия жилого помещчения из владения собственника помимо его воли, предложен новый способ защиты нарушенных прав «добросовестного приобретателя» и не владеющего собственника. В ичелях реализации принципа верховенства права при виндикации, подготовлень конструктивные предложения по внесению изменений в гражданское и жилищное законодательство: - сформулированы изменения в статью 302 Гражданского кодекса Российской Федерации; - предложено дополнить раздел IV Жилищного кодекса Российской Федерации статьей 109.1.
\end{abstract}

Ключевые слова: Юриспруденция, виндикация, истребование, жилое, помещение, собственник, верховенство, собственность, добросовестный, приобретатель

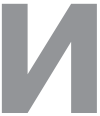

стребование жилого помещения из чужого незаконного владения в настоящее время получило противоречивую правоприменительную практику, что вызывает необходимость исследования в теории гражданского права.

Цель данного исследования - выявить правовое решение проблемы столкновения притязаний не владеющего жилым помещением собственника с притязаниями владеющего этим жилым помещением не собственника «добросовестного приобретателя»-в аспекте реализации принципа верховенства права.

Полагаем, что одной из причин возникающих сложностей в правоприменительной сфере при виндикации недвижимого имущества является нарушение принципа верховенства права, объединяющего в себе требования правовой определенности, правовой эффективности и баланса интересов (пропорциональности) ${ }^{1}$. В этой связи справедливо отметил В.В. Ершов, что «теоретически спорно, а практически малопродуктивно с позиции действительной и эффективной защиты прав и правовых интересов физических и юридических лиц сводить «всё» внутригосударственное право только к «законодательству», нормативным правовым актам, содержащим нормы права ... к внешним формам российского права

\footnotetext{
${ }^{1}$ Нешатаева Т.Н. Уроки судебной практики о правах человека: европейский и российский опыт. М.: Городец, 2007.
}

... возможно относить основополагающие принципы российского права ...»².

В рамках настоящего исследования правовая определенность («res judicata») исследуется в материально-правовом аспекте. Правовая определенность не закреплена в российском законодательстве в качестве принципа права, вместе с тем, Конституционный Суд РФ определяет ее как «определенность, ясность, недвусмысленность правовой нормы», которая вытекает «из конституционных принципов равенства и справедливости..., поскольку иное не может обеспечить ее единообразное применение, не исключает неограниченное усмотрение в правоприменительной практике и, следовательно, неизбежно ведет к произволу» . Более того, в юридической литературе

\footnotetext{
${ }^{2}$ B.B. Ершов. Правосудие, правопонимание и правотворчество в условиях глобализации с позиции легизма и «широкого» понимания права // Российское правосудие. № 12 (68), 2011. С. 15-16.

${ }^{3}$ Постановление Конституционного Суда РФ от 27 ноября 2008 г. N 11-П «По делу о проверке конституционности части второй статьи 5 Федерального закона «О минимальном размере оплаты труда» в связи с жалобами граждан А.Ф. Кутиной и А.Ф. Поварнициной» // СЗ РФ. 2008. N 51. Ст. 6205; Постановление Конституционного Суда РФ от 15 июля 1999 г. N 11-П «По делу о проверке конституционности отдельных положений Закона РСФСР «О Государственной налоговой службе РСФСР» и Законов Российской Федерации «Об основах налоговой системы в Российской Федерации» и «О федеральных органах налоговой полиции» // СЗ РФ. 1999. N 30. Ст. 3988.
} 
выделяется такой критерий правовой определенности как предсказуемость законодательного регулирования, чтобы участники правовых отношений могли быть уверены в стабильности своего правового статуса ${ }^{4}$.

Рассмотрим нормы права и судебную практику в контексте правовой определенности. Правоотношения по истребованию жилого помещения из чужого незаконного владения не урегулированы нормами жилищного права, относятся к сфере правового регулирования нормами гражданского права. В порядке статьи 302 Гражданского кодекса Российской Федерации (далее - ГК РФ) собственник вправе истребовать имущество от добросовестного приобретателя в случае, когда имущество выбыло из его владения или владения лица, которому имущество было передано собственником во владение, помимо воли 5 . Пленум Верховного Суда РФ N 10 и Пленум ВАС РФ N 22 от 29.04.2010 г. в совместном постановлении «О некоторых вопросах, возникающих в судебной практике при разрешении споров, связанных с защитой права собственности и других вещных прав» ${ }^{6}$ в пунктах 36-39 разъяснил, что добросовестность приобретения слагается из двух составляющих: приобретатель не знал и не должен был знать и принял все разумные меры для выяснения правомочий продавца на отчуждение имущества. Вместе с тем, при оценке выбытия имущества помимо воли собственника ни законодателем, ни судами не выработаны критерии оценки выбытия имущества помимо воли собственника, что привело к правовой неопределенности, поскольку истребование имущества происходит во всех случаях, независимо от добросовестности приобретателя при доказанности выбытия имущества помимо воли собственника, которое не имеет критериев оценки.

Таким образом, требование правовой определенности в рамках виндикации не соблюдается. Представляется, что необходимо сформулировать критерии оценки выбытия жилого помещения из владения собственника помимо его воли, от чего зависит «судьба» вещи и права собственности на нее. В отношении собственника - физического лица - критерий совершения им действий, препятствующих выбытию имущества из его владения, и критерий применения исчерпывающего

\footnotetext{
${ }^{4}$ М.В. Пресняков. Правовая определенность как системное качество российского законодательства // Журнал российского права, 2009, N 5.

${ }_{5}^{5}$ Гражданский кодекс Российской Федерации (часть первая) от 30.11.1994 N 51-Ф3 (ред. от 30.11.2011) // Собрание законодательства РФ, 05.12.1994, N 32, ст. 3301.

${ }^{6}$ Постановление Пленума Верховного Суда РФ N 10, Пленума ВАС РФ N 22 от 29.04.2010 г. «О некоторых вопросах, возникающих в судебной практике при разрешении споров, связанных с защитой права собственности и других вещных прав» // Бюллетень Верховного Суда РФ, N 7, июль, 2010.
}

перечня способов защиты его нарушенного права собственности. В отношении собственника - публичного образования (например, город Москва) - критерий недопустимости компетентными органами государственной власти совершать ошибки (халатность), повлекшие выбытие жилого помещения из его владения, поскольку это не может служить основанием для возложения бремени несения расходов по возмещению ущерба на «добросовестного приобретателя».

Интересно рассмотреть некоторые вопросы виндикации на предмет правовой эффективности. В пункте 43 вышеуказанных разъяснений Пленумов Судов указано на то, что в случае, если иск собственника об истребовании имущества из чужого незаконного владения удовлетворен, покупатель чужого имущества вправе в соответствии со статьей 461 ГК РФ обратиться в суд с требованием к продавцу о возмещении убытков, причиненных изъятием товара по основаниям, возникшим до исполнения договора купли-продажи. На практике продавцом жилых помещений, выбывших помимо воли собственника, зачастую выступают недобропорядочные граждане, что создает непреодолимые трудности при защите прав покупателя в порядке статьи 461 ГК РФ. Такой способ защиты прав «добросовестного приобретателя» не способен защитить нарушенные права граждан, поэтому является неэффективным. В целях достижения правовой эффективности норм права с учетом правовой определенности, предложенной выше, необходимо внести изменения в действующее жилищное законодательство в части наделения «проигравшую» дело сторону, оставшуюся без жилья, новым способом защиты нарушенных прав, а именно: правом на обращение в суд с требованием к соответствующему компетентному органу государственной власти о предоставлении жилого помещения по договору краткосрочного найма.

Обратимся к исследованию третьего требования верховенства права - к требованию соблюдения баланса интересов (пропорциональности). В этой связи рассмотрим резонансное дело Европейского Суда по правам человека «Гладышева против России», по результатам рассмотрения которого Суд признал нарушение Российской Федерацией прав заявительницы, гарантированных Европейской конвенцией о защите прав человека и основных свобод (далее - Конвенция), и указал на необходимость их восстановления путем предоставления жилого помещения. Вместе с тем, Суд дал правовую оценку принципу соблюдения баланса интересов собственника и «добросовестного приобретателя»7.

\footnotetext{
7 Постановление Европейского Суда по правам человека от 06.12.2011 г. По делу «Гладышева против России» (жалоба № $7097 / 10$ ).
} 


\section{Право и политика 6 (162) 2013}

Из содержания постановления Суда следует, что нарушение баланса интересов (пропорциональности) имеет место при нарушении субъективных прав гражданина, в частности жилищных прав, когда гражданин лишается того, на что в силу закона имеет право. В этой связи важно рассмотреть две модели ситуаций: когда собственником выступает государство и «добросовестным приобретателем» физическое лицо и когда обеими сторонами являются физические лица. Действительно, при виндикации жилого помещения государством у «добросовестного приобретателя», который лишается спорного жилого помещения, являющегося единственным, имеет место нарушение баланса интересов, поскольку право «добросовестного приобретателя» является реализованным, право же неопределенного круга иных граждан, в интересах которых государство истребует жилое помещение, не реализовано, при этом неизвестно когда и кто его реализует. В ситуации, когда обе стороны являются физическими лицами, нарушение баланса также будет иметь место, поскольку оба права реализованы, обе стороны имеют притязания на спорный объект. В случае и удовлетворения, и отказа в удовлетворении искового требования о виндикации жилого помещения одна из сторон конфликта остается без жилого помещения, на которое имеет право в силу закона или договора. В этой связи нарушается баланс интересов (пропорциональность), что недопустимо в правовом государстве. В целях соблюдения баланса интересов (пропорциональности), при рассмотрении дела по существу судам, с одной стороны, при доказанности «добросовестности» приобретения жилого помещения и, с другой, при доказанности выбытия такового помимо воли собственника следует учитывать наличие у «добросовестного приобретателя» и не владеющего собственника иных жилых помещений, их доходность, возможность приобрести иное жилое помещение.

Полагаем, что с учетом рассмотренной реализации составляющих принципа верховенства права, данный принцип, в контексте функционирования механизма виндикации жилого помещения у «добросовестного приобретателя», не соблюдается, что вызывает острую необходимость во внесении в гражданское законодательство изменений следующего содержания.

1). В целях достижения правовой определенности представляется целесообразным внести изменения в статью 302 ГК РФ, а именно дополнить пункт 1 статьи 302 ГК РФ вторым и третьим абзацами в следующей редакции:

«Критерием оценки выбытия жилого помещения помимо воли собственника физического лица является критерий совершения им действий, препятствующих выбытию имущества из его владения, и критерий применения исчерпывающего перечня способов защиты его нарушенного права собственности.

Критерием оценки выбытия жилого помещения помимо воли собственника публичного образования является критерий не совершения компетентными органами государственной власти ошибки (халатности), повлекшей выбытие жилого помещения из его владения.».

2). В целях соблюдения баланса интересов (пропорциональности) и достижения правовой эффективности целесообразно внести изменения в ЖК РФ, а именно дополнить раздел IV статьей 109.1 в следующей редакции:

«Гражданин, признанный судом «добросовестным приобретателем» и у которого собственником истребовано единственное жилое помещение, вправе обратиться в уполномоченный орган с заявлением о предоставлении жилого помещения по договору найма специализированного жилого помещения.».

Изложенные предложения по изменению законодательства, в частности «реабилитационная процедура», позволят защитить права граждан, лишенных единственного жилого помещения по независящим от них обстоятельствам, и будут служить одной из гарантий реализации конституционного права каждого на жилище.

\section{Библиография:}

1. В.В. Ершов. Правосудие, правопонимание и правотворчество в условиях глобализации с позиции легизма и «широкого» понимания права // Российское правосудие. № 12 (68), 2011. С. 15-16.

2. М.В. Пресняков. Правовая определенность как системное качество российского законодательства // Журнал российского права, 2009, N 5.

3. Нешатаева Т.Н. Уроки судебной практики о правах человека: европейский и российский опыт. М.: Городец, 2007.

4. Гражданский кодекс Российской Федерации (часть первая) от 30.11.1994 N 51-Ф3 (ред. от 30.11.2011) // Собрание законодательства РФ, 05.12.1994, N 32, ст. 3301.

5. Постановление Европейского Суда по правам человека от 06.12.2011 г. По делу «Гладышева против России» (жалоба № 7097/10).

6. Постановление Конституционного Суда РФ от 27 ноября 2008 г. N 11-П «По делу о проверке конституционности части второй статьи 5 Федерального закона «О минимальном размере оплаты труда» в связи с жалобами граждан А.Ф. Кутиной и А.Ф. Поварнициной» // С3 РФ. 2008. N 51. Ст. 6205.

7. Постановление Конституционного Суда РФ от 15 июля 1999 г. N 11-П «По делу о проверке конституционности отдельных положений Закона РСФСР 
Юридический практикум

«О Государственной налоговой службе РСФСР» и Законов Российской Федерации «Об основах налоговой системы в Российской Федерации» и «О федеральных органах налоговой полиции» // С3 РФ. 1999. N 30. Ст. 3988.

8. Постановление Пленума Верховного Суда РФ N 10 , Пленума ВАС РФ N 22 от 29.04.2010 г. «О некоторых вопросах, возникающих в судебной практике при разрешении споров, связанных с защитой права собственности и других вещных прав»// Бюллетень Верховного Суда РФ, N 7, июль, 2010.

\section{References (transliteration):}

1. V.V. Ershov. Pravosudie, pravoponimanie i pravotvorchestvo $\mathrm{v}$ usloviyah globalizacii s pozicii legizma $\mathrm{i}$ «shirokogo» ponimaniya prava // Rossiyskoe pravosudie. № 12 (68), 2011. S. 15-16.

2. M.V. Presnyakov. Pravovaya opredelennost' kak sistemnoe kachestvo rossiyskogo zakonodatel'stva // Zhurnal rossiyskogo prava, 2009, N 5.

3. Neshataeva T.N. Uroki sudebnoy praktiki o pravah cheloveka: evropeyskiy i rossiyskiy opyt. M.: Gorodec, 2007. 